\title{
Implementasi Kebijakan Tax Allowance Dalam Upaya Peningkatan Iklim Investasi Pada Sektor Kelautan Dan Perikanan
}

\author{
Wiji Mutia Hardianti ${ }^{1}$, Milla Sepliana Setyowati ${ }^{2}$
}

\begin{abstract}
ABSTRAK
Sebagai Negara kepulauan dengan luas area perairan sebesar 5.8 juta $\mathrm{km}^{2}$, sektor kelautan dan perikanan Indonesia menyimpan potensi sumber daya alam yang sangat besar. Total produksi perikanan Indonesia mencapai 25 juta ton setiap tahun dan telah memberikan kontribusi terhadap Produk Domestik Bruto sebesar 6.79\% pada Triwulan III Tahun 2017. Oleh karenanya sektor kelautan dan perikanan kini telah menjadi salah satu sektor yang menjadi prioritas nasional. Salah satu upaya dalam mendorong pembangunan sektor kelautan dan perikanan yang dilakukan pemerintah adalah dengan menerbitkan kebijakan fasilitas pengurangan pajak penghasilan untuk penanaman modal (tax allowance) dalam rangka menarik investor dalam negeri dan luar negeri. Penelitian ini bertujuan untuk menganalisis implementasi dari kebijakan tax allowance pada bidang-bidang usaha tertentu dan daerah-daerah tertentu di sektor perikanan. Penelitian ini menggunakan pendekatan kualitatif dengan teknik pengumpulan data melalui wawancara mendalam dan data sekunder. Hasil awal menunjukkan bahwa fasilitas tax allowance ini belum dimanfaatkan secara optimal pada sector kelautan dan perikanan. Implementasi dapat dipengaruhi oleh konten dari kebijakan dan konteks dari implementasi itu sendiri. Kementerian Kelautan dan Perikanan harus meriviu bidang usaha yang tepat untuk diberikan fasilitas tax allowance dan melaksanakan sosialisasi secara intensif.
\end{abstract}

Kata kunci : Implementasi Kebijakan, Tax Allowance, Sektor Perikanan

\begin{abstract}
As an archipelagic country with 5.8 million $\mathrm{km}^{2}$ of water area, marine and fisheries' sector hold enormous potential of natural resources. Indonesia's total production of fisheries reach 25 million tons per years and has contributed to Gross Domestic Product (GDP) with 6.79\% in Q3 2017. Thus, marine and Fisheries' sector has become one of the national priority. In order to boost the development of these sectors, the government has launched a policy in reducing income tax facility for investment (tax allowance) which is targeting domestic and foreign investment. This study aims to analyze the implementation of tax allowance facility in the certain business fields and certain areas of fishery sectors. This study uses a qualitative approach with data collection methods in the form of in depth interview and secondary data. The preliminary result shows that the tax facility is not well-utilized by the investors in fishery sectors. The policy contents and context of implementation can affect the policy implementation. The Ministry of Marine Affairs and Fisheries must review the appropriate business fields to be given the tax allowance facility and concuct the socialization intensively.
\end{abstract}

Keywords: Policy Implementation, Tax Facility, Fishery Sector

\footnotetext{
${ }^{1}$ Fakultas Ilmu Administrasi, Universitas Indonesia; email : wiwimutiah@kkp.go.id

${ }^{2}$ Dosen Fakultas Ilmu Administrasi, Universitas Indonesia; email : milla.s.setyowati
} 


\section{PENDAHULUAN}

Sebagai Negara kepulauan dengan luas perairan sebesar 5.8 juta $\mathrm{km}^{2}$ dan garis pantai yang terpanjang diantara negara-negara kepulauan lainnya yaitu $95.181 \mathrm{~km}$, sektor kelautan dan perikanan Indonesia menyimpan potensi yang sangat besar. Dalam konteks perdagangan global, Indonesia saat ini tengah menguatkan posisinya sebagai poros maritim dunia. Hal ini diperkuat dengan visi baru Indonesia dibidang maritim yang tertuang di dalam salah satu poin Nawa Cita yaitu memperkuat jati diri sebagai Negara Maritim.

Sektor perikanan Indonesia perlu mendapatkan perhatian khusus dengan prospektif perekonomiannya yang besar. Menurut Laporan Kinerja KKP Tahun 2018, hasil produksi perikanan laut Indonesia yang terdiri dari produksi perikanan budidaya dan perikanan tangkap mencapai 24,29 juta. Jumlah ini naik $1,41 \%$ dari tahun sebelumnya yakni 24,15 juta ton. Nilai ekspor hasil perikanan Indonesia juga mengalami kenaikan sebesar $7.52 \%$ yaitu 4.52 miliar pada 2017 menjadi 4,86 miliar USD pada tahun 2018. Sektor perikanan juga telah memberikan bukti nyata dengan Hasil Produksi Perikanan yang berkontribusi besar terhadap Produk Domestik Bruto (PDB) seperti yang dapat dilihat pada Gambar 1. Walaupun nilai PDB Perikanan tampak fluktuatif dari tahun ke tahun, namun sumbangsih produksi perikanan terhadap PDB selalu lebih tinggi dari sub sektor pertanian dan bahkan PDB Nasional.

Pertumbuhan PDB perikanan sampai dengan Triwulan III Tahun 2017 mencapai angka 6.79\% sedangkan pertumbuhan PDB Nasional masih di angka $5.03 \%$. Hasil produksi perikanan menunjukkan nilai yang positif dan diperkirakan akan terus meningkat. Besarnya potensi ini menunjukkan sektor perikanan dan kelautan akan menjadi sektor yang prospektif bagi perekonomian nasional.

Adapun target PDB Perikanan pada tahun 2019 tercatat didalam Renstra KKP Tahun 20152019 , yakni sebesar $11 \%$. Rencana aksi yang akan dilakukan dalam upaya meningkatkan PDB
Perikanan dimasa depan adalah melalui peningkatan produksi perikanan, perbaikan iklim investasi, dan perbaikan supply chain dari hulu sampai hilir.

\section{Gambar 1. \\ Kontribusi Sektor Perikanan terhadap PDB s.d Triwulan III Tahun 2017}

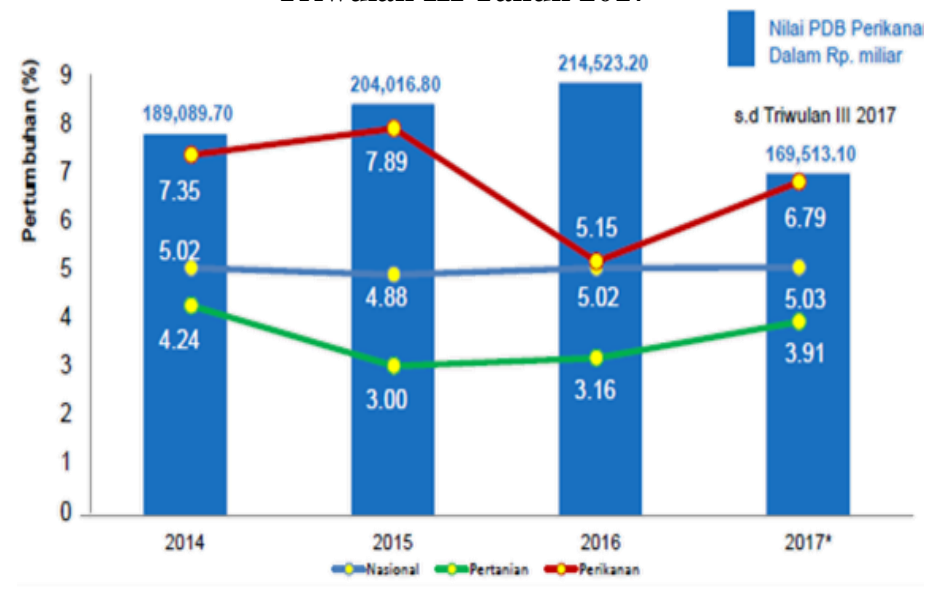

Sumber : Badan Pusat Statistik, 2017

Dibalik potensi ekonomi yang besar, terdapat beberapa isu dalam pengelolaan perikanan laut di Indonesia yang juga berpotensi mengancam pertumbuhan ekonomi khususnya yang bersumber dari pemanfaatan sumber daya kelautan dan perikanan seperti; penurunan jumlah rumah tangga perikanan, terbatasnya infrastruktur pada pengembangan perikanan budidaya dan usaha perikanan, rendahnya produktivitas daya saing usaha kelautan dan perikanan dikarenakan belum optimalnya integrasi sistem produksi di hulu dan hilir, lemahnya daya saing dan produktivitas juga disebabkan oleh kualitas, keterbatasan dukungan permodalan usaha dari pihak perbankan dan lembaga keuangan lainnya kepada para nelayan/ pembudidaya.

Potensi lestari sektor perikanan memperlihatkan bahwa jantung kehidupan perikanan Indonesia terus berdetak. Untuk mengurus dan menjaganya agar tidak berhenti, maka dibutuhkan suatu kebijakan strategis agar semua potensi itu dapat dikelola dengan baik. Salah satu kebijakan pokok yang tertuang dalam Renstra KKP Tahun 2015-2019 adalah meningkatkan pemberdayaan, 
daya saing, dan kemandirian dalam menjaga keberlanjutan usaha kelautan dan perikanan yang dilakukan dengan cara meningkatkan usaha dan investasi kelautan dan Perikanan. Adapun sasaran peningkatan industri usaha perikanan adalah (1) Pertumbuhan PDB perikanan sebesar 7.2 persen per tahun; (2) Peningkatan nilai ekspor hasil perikanan menjadi USD 9.5 miliar pada tahun 2019; (3) Peningkatan produk olahan perikanan menjadi 6.8 juta ton pada tahun 2019 .

Tantangan yang dihadapi bukan hanya tentang penegakan kedaulatan laut Indonesia, namun juga tentang bagaimana mengembangkan industri kelautan dan perikanan dengan mengoptimalkan upaya pendayagunaan potensi laut bagi kesejahteraan rakyat Indonesia. Pemerintah melalui Kementerian Kelautan dan Perikanan beberapa tahun terakhir sangat gencar melakukan strategi untuk memberantas praktik Illegal, Unregulated, and Unreported (IUU) Fishing. Salah satu upayanya dengan menetapkan Peraturan Presiden Nomor 44 Tahun 2016 tentang Daftar Bidang Usaha yang Tertutup dan Bidang Usaha yang Terbuka dengan Persyaratan di Bidang Penanaman Modal. Dengan aturan ini, usaha sektor perikanan tangkap sepenuhnya harus berasal dari dalam negeri. Sedangkan untuk investor asing, Indonesia tetap memberikan kesempatan hingga 100 persen untuk berinvestasi pada kegiatan hilir perikanan yaitu usaha pengolahan ikan.

Kementerian Kelautan dan Perikanan juga telah mulai melaksanakan suatu Program Percepatan Industri Perikanan sebagai upaya tindak lanjut dari terbitnya Instruksi Presiden Nomor 7 Tahun 2016 tentang Percepatan Pembangunan Indsutri Perikanan Nasional. KKP mulai membangun Sentra Kelautan dan Perikanan Terpadu (SKPT) sebagai industri baru di kawasan pulau-pulau terluar yang dekat dengan gateaway ekspor. Dirjen Pengelolaan Ruang Laut KKP, Brahmantya Satyamurti Poerwadi, dalam buku "Laut Kita Masa Depan Bangsa" (2018), mengatakan bahwa dalam pembangunan SKPT tersebut Indonesia membutuhkan investasi fasilitas cold storage, industri pengolahan, pembangunan pelabuhan, pembangunan kapal, coaching, dan sebagainya. Dengan adanya revitalisasi melalui investasi ini, diharapkan industri perikanan bisa bergerak maju dan ekspor bisa terus bertumbuh.

Berdasarkan data dari Badan Koordinasi Penanaman Modal (BKPM) Indonesia, realisasi Domestic Direct Investment (DDI) dan Foreign Direct Investment (FDI) menurut sektor di Indonesia menunjukkan hasil yang jauh tertinggal dibandingkan sektor-sektor lainnya. Persentase kontribusi realisasi investasi sektor perikanan terhadap realisasi investasi nasional tidak bergerak naik dari angka $0.1 \%$ tiap tahunnya, dengan nilai investasi terbesar pada tahun 2015 yaitu sebesar Rp. 0,7 Triliun. Dengan potensi sumber daya kelautan dan perikanan yang besar, seharusnya investasi dapat terus didorong untuk memperkuat industri perikanan nasional.

Investasi diharapkan dapat menghasilkan multiplier effects terhadap pembangunan ekonomi nasional, karena kegiatan investasi tidak hanya mentransfer barang dan modal, namun juga mentransfer ilmu pengetahuan (Ridgway dan Thalib, 2003). Untuk menarik investor melakukan penanaman modal di industri perikanan ini, Indonesia telah menawarkan beberapa kemudahan. Salah satunya adalah fasilitas keringanan pajak penghasilan badan bagi penanam modal asing maupun dalam negeri yang berminat berinvestasi. Menurut riset dari Wulandari (2013), pemberian insentif pajak kepada investor dilakukan dengan argumen bahwa Negara akan menderita kerugian jangka pendek akibat berkurangnya pendapatan Negara dari penerimaan pajak, namun Negara akan mendapatkan keuntungan yang lebih besar dalam jangka panjang.

Insentif Pajak Penghasilan untuk penanaman modal ini berlandaskan Pasal 31A Undangundang Nomor 36 Tahun 2008 tentang Pajak Penghasilan. Pemerintah telah menerbitkan Peraturan Pemerintah No 18 Tahun 2015 sebagaimana telah diubah menjadi Peraturan Pemerintah Nomor 9 Tahun 2016 mengenai pemberian fasilitas tax allowance (pengurangan 
pajak penghasilan) untuk penanaman modal di bidang-bidang usaha tertentu dan/atau di daerahdaerah tertentu guna mendongkrak pertumbuhan ekonomi. Fasilitas ini ditujukan bagi wajib pajak badan dalam negeri yang melakukan penanaman modal baru maupun perluasan usaha yang telah ada, sepanjang memenuhi kriteria memiliki nilai investasi yang tinggi atau untuk ekspor, memiliki penyerapan tenaga kerja yang besar, dan memiliki kandungan lokal yang tinggi.

Sebagai aturan turunan, Kementerian Kelautan dan Perikanan (KKP) menerbitkan peraturan pelaksana dari Peraturan Pemerintah tersebut yaitu Peraturan Menteri Kelautan dan Perikanan Nomor 17 Tahun 2015 tentang Kriteria dan/atau Persyaratan Pemberian Fasilitas Pajak Penghasilan Untuk Penanaman Modal di BidangBidang Usaha Tertentu dan/atau di DaerahDaerah Tertentu Pada Sektor Kelautan dan Perikanan. Dalam aturan ini dijelaskan bahwa pemberian fasilitas pajak penghasilan yaitu dengan kriteria; memiliki nilai investasi tinggi (paling sedikit 10 - 50 milyar) atau untuk ekspor (paling sedikit 30\% - 80\% hasil produk diekspor) atau memiliki penyerapan tenaga kerja yang besar (paling sedikit 90\% tenaga kerja Indonesia). Sebanyak sebelas bidang usaha di sektor kelautan dan perikanan akan diberikan insentif fiskal berupa fasilitas keringan pajak (tax-allowance).

Pemerintah dari tahun ke tahun telah melakukan perubahan Peraturan Pemerintah yang mengatur tentang pemberian tax allowance dengan menambahkan jumlah Klasifikasi Baku Lapangan Usaha Indonesia (KBLI) yang dapat diberikan fasilitas tersebut. Namun pemanfaatan fasilitas tax allowance pada usaha-usaha sektor kelautan dan perikanan sendiri masih belum maksimal. Data dari Direktorat Usaha dan Investasi KKP menunjukkan bahwa realisasi perusahaan yang mendaftar untuk diberikan fasilitas tax allowance di usaha sektor perikanan ini terbilang nihil pada tahun 2016, sedangkan pada tahun 2017 tercatat hanya 1 perusahaan yang terdaftar untuk diberikan tax allowance dengan nama perusahaan "Indomina Langgeng Abadi" yang berasal dari Lampung. Perusahaan ini memiliki kegiatan usaha di bidang budidaya dan pengolahan udang, dengan nilai investasi sebesar 200 milyar. Dan terdapat satu perusahaan yang sedang dalam proses pertimbangan untuk mendapatkan tax allowance.

Kajian mengenai tax allowance juga pernah dilakukan oleh seorang Mahasiswa Fakultas Hukum Universitas Indonesia bernama Ian Maradona pada tahun 2013 dalam paper yang berjudul "Implikasi Ketentuan Insentif Pajak (Holiday/Tax Allowance) terhadap Penanaman Modal di Indonesia". Hasil penelitiannya menunjukkan bahwa dengan diundangkannya peraturan pemberian insentif pajak tersebut belum dapat dipastikan meningkatkan kuantitas investasi di Indonesia (Nunung; 2017). Temuan lainnya bahwa kebijakan fiskal berupa fasilitas perpajakan tidak dapat berbuat banyak apabila faktor penghambat investasi seperti mogok buruh, perijinan yang rumit dan rawan pungutan liar, prosedur pengurusan izin yang kurang efisien, dan korupsi masih marak di Indonesia.

Peneliti membatasi pembahasan penelitian ini yaitu mengenai kebijakan tax-allowance pada bidang usaha tertertu dan daerah tertentu pada sektor kelautan dan perikanan yang diimplementasikan di Kementerian Kelautan dan Perikanan. Fasilitas tersebut dimaksudkan untuk meningkatkan investasi pada Industri Perikanan Nasional sehingga berdampak pada peningkatan ekspor dan penyerapan tenaga kerja. Dengan pemahaman yang memadai mengenai fasilitas tax allowance tersebut, diharapkan peneliti dapat melakukan analisa terhadap penerapan kebijakan tax-allowance dalam rangka mendorong investasi di Kementerian Kelautan dan Perikanan serta faktor pendukung dan penghambat dalam penerapan kebijakan tersebut.

\section{KERANGKA TEORI}

\section{Implementasi Kebijakan}

Keputusan pemerintah untuk membuat suatu kebijakan bermula dari munculnya permasalahan publik yang dirasa perlu untuk dicari solusinya. 
Untuk menyusun suatu kebijakan, diperlukan setidaknya 6 tahapan seperti yang dikemukakan oleh Lester and Stewart (2000), diantaranya; (1) Agenda Setting; (2) Policy Formulation; (3) Policy Implementation; (4) Policy Evaluation; (5) Policy Change; (6) Policy Termination.

Implementasi kebijakan merupakan tahapan ketiga dari suatu siklus kebijakan. Implementasi dapat digambarkan sebagai suatu proses, output, atau hasil. Proses implementasi didefinisikan sebagai serangkaian keputusan dan tindakan pemerintah yang diarahkan untuk menerapkan suatu amanat yang sudah ditentukan menjadi suatu hasil yang terlihat. Istilah output dari implementasi sendiri mengacu pada sarana yang digunakan untuk mencapai tujuan program, misalnya pengeluaran Negara untuk menyelesaikan berbagai masalah publik. Sedangkan outcomes dari implementasi merupakan perubahan dalam masalah sosial yang lebih besar yang ingin diperbaiki oleh suatu program. (Lester and Stewart, 2000 : 10)

Adapun pendapat lain dari Grindle (1980:7) yaitu memandang implementasi sebagai suatu proses umum dari tindakan administratif yang dapat diteliti pada level program tertentu. Sukses atau tidaknya suatu implementasi dapat dilihat dengan mengukur hasil program terhadap sasaran kebijakan. Proses implementasi sendiri dimulai ketika tujuan dan sasaran telah ditentukan, saat rencana aksi telah dirancang, dan ketika dana sudah dialokasikan untuk pencapaian tujuan.

Selanjutnya Grindle mengemukakan dua variabel yang mempengaruhi keberhasilan suatu implementasi kebijakan yaitu Content of Policy dan Context of Implementation. Adapun penjelasan dari model implementasi kebijakan Grindle berdasarkan gambar diatas adalah sebagai berikut :

1. Content of Policy (Isi Kebijakan)

Beberapa indikator variabel yang mempengaruhi kebijakan adalah:

a. Interest Affected (kepentingan kelompok sasaran)

b. Type of Benefit (tipe manfaat) c. Extent of Exchange Envinsion (derajat perubahan yang ingin dicapai)

d. Site of Decision Making (letak pengambilan keputusan)

e. Program Implementer (pelaksana program)

f. Resources committed (ketersediaan sumber daya)

2. Context of Implementation (Variabel lingkungan implementasi)

a. Kekuasaan, kepentingan, dan strategi dari aktor yang terlibat;

b. Karakteristik dari lembaga dan rezim yang berkuasa;

c. Compliance (kepatuhan) dan Responsiveness (respon dari pelaksana kebijakan).

\section{Insentif Pajak untuk Penanaman Modal/ Tax Allowance}

Nigel A. Chalk dalam Santoso dan Rahayu (2013) mengemukakan alasan pemberian insentif pajak, diantaranya: (1) industrial policy, khususnya mendorong gerak majunya industri tertentu; (2) the transfer of proprietary knowledge or technology, secara khusus ditujukan pada investor dengan skala industri makro untuk dapat mentransfer pengetahuan dan alih teknologi; (3) employment objectives, berupa penciptaan lapangan kerja baru; (4) training and human capital development, guna peningkatan kualitas sumber daya manusia; (5) economic diversification, dalam hal ekspektasi tumbuhnya sektor industry baru; (6) access to overseas market, menstimulasi perdagangan internasional untuk mendorong kegiatan ekspor; (7) regional or locational objectives, untuk mempercepat pertumbuhan wilayah yang menjadi target pemberian insentif pajak.

Insentif pajak dapat didefinisikan sebagai ketentuan pajak khusus yang diberikan kepada proyek investasi yang memenuhi syarat (Kristian; 2018). Di dalam buku Tax Incentives for Foreign Direct Investment, Easson (2004) menjelaskan bawa faktor paling penting dari insentif pajak yang efektif adalah spesial atau khusus dan tidak 
umum, jadi jika diberikan kepada semua investor maka bukanlah termasuk ke dalam insentif pajak, walaupun perlakuan tersebut mungkin hanya dapat memberikan keuntungan kepada beberapa investor saja. Karenanya harus dibuat perbedaan antara ketentuan yang merupakan insentif atau yang diberikan secara umum, walaupun hal ini sangat sulit untuk dilakukan.

Menurut Turonyi (1998), Tax Allowance digunakan untuk mengurangi penghasilan kena pajak. Dalam mendesain tax allowancelinvesment allowances beberapa faktor yang dipertimbangkan adalah:

a. Eligible invesment. Pemberian invesment allowances dapat diberikan untuk semua bentuk investasi, atau hanya diberikan untuk kategori yang spesifik.

b. Amount of the allowance. Bentuk dari invesment allowances dapat berupa persentase dari investasi yang memenuhi syarat. Biasanya variasinya tergantung kepada tipe dari aset yang menjadi subjek investasi, tipe aktivitas yang dilakukan investor, lokasi dari investasi dan faktor lainnya.

c. Duration and other restriction. Pembatasan jangka waktu dari pemberian invesment allowances.

\section{METODE PENELITIAN}

Penelitian ini menggunakan pendekatan kualitatif deskriptif yaitu mencari jawaban atas pertanyaan penelitian dengan mengumpulkan bukti-bukti. Pengumpulan data dilakukan melalui studi pustaka dan studi lapangan. Studi pustaka dilakukan dengan membaca serta mempelajari berbagai literatur, paper, jurnal ilmiah, regulasi, dokumen-dokumen dan laporan-laporan yang berkaitan dengan penelitian yang sedang dilakukan. Studi lapangan dilakukan melalui wawancara mendalam dengan para pembuat kebijakan dan pelaksana kebijakan. Informan ditentukan dengan teknik key person yaitu mewawancarai narasumber yang mempunyai cukup informasi mengenai objek yang diteliti. Adapun narasumber dalam penelitian ini berasal dari Kementerian Kelautan dan Perikanan, Direktorat Jenderal Pajak, Badan Kebijakan Fiskal, Badan Koordinasi dan Penanaman Modal, dan Kementerian Koordinator Bidang Perekonomian. Proses pengumpulan data telah dilakukan sejak bulan April 2019 hingga Juli 2019.

Analisis data pada penelitian ini menggunakan logika induktif dimana dikumpulkannya data-data khusus di lapangan, menjabarkannya ke dalam unit-unit, memilih mana yang penting dan akan dipelajari, kemudian dianalisis hingga diperoleh suatu kesimpulan yang umum. Validasi data dilakukan dengan triangulasi sumber dan triangulasi teknik. Triangulasi sumber dilakukan dengan menguji kredibilitas data dengan menanyakan pertanyaan yang sama kepada sumber yang berbeda. Sedangkan triangulasi teknik dilakukan dengan menguji data pada sumber yang sama dengan teknik yang berbeda yaitu wawancara dan data sekunder.

\section{PEMBAHASAN}

\section{Content of Policy}

Adapun beberapa indikator variabel yang mempengaruhi kebijakan adalah:

\section{a. Interest Affected}

Grindle (1980) berpendapat bahwa implementasi suatu kebijakan dikatakan berhasil apabila kebijakan yang dibuat dapat memberikan pengaruh kepada kelompok sasaran dari kebijakan tersebut. Merujuk pada Peraturan Pemerintah No. 18 Tahun 2015 jo. Peraturan Pemerintah No. 9 Tahun 2016 bahwa kelompok sasaran dari kebijakan tax allowance ini adalah pelaku usaha yang belum berproduksi komersial. Asumsinya adalah bahwa perusahaan yang sudah berproduksi komersial berarti sudah bisa survive tanpa perlu government support dalam bentuk fasilitas pajak.

Hal tersebut ditegaskan dalam wawancara dengan Kepala Seksi Pelayanan Usaha Direktorat Usaha dan Investasi Kementerian Kelautan dan 
Perikanan yang menyatakan bahwa prinsipnya fasilitas ini diberikan untuk merangsang investor, baik untuk penanaman modal baru maupun perluasan usaha yang sudah ada. Jika seseorang sudah berproduksi komersial, dan sudah exist, maka tidak perlu lagi diberikan fasilitas. Namun saat orang mau membuka usaha di suatu daerah yang dekat dengan bahan baku, namun ketersediaan infrastruktur tidak mendukung, sulitnya akses air bersih, akses listrik, dan sebagainya sehingga mereka perlu government support agar dapat berinvestasi disana.

Adapun kenyataan di lapangan bahwa sebagian pelaku usaha perikanan sektor hilir adalah pelaku usaha yang sudah berproduksi komersial. Direktorat Deregulasi Badan Koordinasi dan Penanaman Modal juga menjelaskan bahwa salah satu kendala pada sektor perikanan adalah kurang berkembangnya sektor hilir berupa usaha pengolahan ikan terutama karena masalah infrasruktur sehingga sulit menarik investor baru. Saat ini sektor perikanan juga masih didominasi oleh sektor hulu yaitu perikanan tangkap yang dilakukan oleh nelayannelayan kecil dan perikanan budidaya oleh kelompok pembudidaya yang tidak termasuk ke dalam sasaran dari penerima fasilitas tax allowance ini.

Insentif pajak dapat didefinisikan sebagai ketentuan pajak khusus yang diberikan kepada proyek investasi yang memenuhi syarat. Di dalam buku Tax Incentives for Foreign Direct Investment, Easson (2004) menjelaskan bawa faktor paling penting dari insentif pajak yang efektif adalah spesial atau khusus dan tidak umum, jadi jika diberikan kepada semua investor maka bukanlah termasuk ke dalam insentif pajak, walaupun perlakuan tersebut mungkin hanya dapat memberikan keuntungan kepada beberapa investor saja. Karenanya harus dibuat perbedaan antara ketentuan yang merupakan insentif atau yang diberikan secara umum, walaupun hal ini sangat sulit untuk dilakukan.

Dalam Peraturan Menteri Kelautan dan Perikanan Nomor 17 Tahun 2015 sudah ditetapkan sejumlah kriteria dan/atau persyaratan pemberian fasilitas pajak penghasilan untuk penanaman modal di bidang-bidang usaha tertentu dan/atau di daerah-daerah tertentu pada sektor kelautan dan perikanan. Kriteria tersebut diantaranya; memiliki nilai investasi tinggi (paling sedikit 10 - 50 milyar) atau untuk ekspor (paling sedikit 30\% - 80\% hasil produk diekspor) atau memiliki penyerapan tenaga kerja yang besar (paling sedikit 90\% tenaga kerja Indonesia).

Salah satu kriteria pada Lampiran II Permen KP 17 Tahun 2015 menyebutkan bahwa usaha perikanan tangkap terpadu adalah usaha perikanan tangkap dengan fasilitas penanaman modal yang terintegrasi dengan pengolahan ikan melalui pembangunan, memiliki Unit Pengolahan Ikan, atau bermitra dengan Unit Pengolahan Ikan. Kriteria ini bisa menjadi penghambat dalam implementasi dikarenakan banyak pengusaha penangkapan ikan yang aset berwujud mereka untuk melakukan usaha adalah berupa kapal dan peralatan penangkapan, tanpa terintegrasi dengan pengolahan ikan atau berada di daerah pelabuhan yang belum mempunyai fasilitas untuk penyimpanan dan pengolahan ikan.

\section{b. Type of Benefit}

Indikator yang menunjukkan bahwa kebijakan yang dibuat dapat menunjukkan atau menjelaskan beberapa manfaat yang memberikan dampak positif yang dihasilkan dari kebijakan. Dalam penerapan pemberian fasilitas pajak, ada tax expenditure yang cukup besar yang akan menjadi beban pemerintah. Namun alasan pemerintah tetap mendukung pemberian fasilitas tersebut adalah karena dalam jangka panjang diharapkan adanya multiplier effects yang akan meningkatkan penerimaan pajak itu sendiri. $\mathrm{Hal}$ ini dipertegas dalam pendapat Irianto dan Rosdiana (2014 : 90), bahwa kebijakan pengurangan beban pajak tidak akan menurunkan penerimaan Negara secara aggregate, bahkan sebaliknya meningkatkan penerimaan Negara dari jenis-jenis pajak lainnya.

Kepala Seksi PPh Badan, Direktorat Jenderal Pajak menyatakan bahwa salah satu kriteria untuk 
dapat memperoleh tax allowance adalah penyerapan tenaga kerja yang besar. Jika suatu usaha baru itu sudah exist dan berproduksi, maka dia akan menumbuhkan ekonomi disekitarnya. Pajak akan dikurangi sekian persen untuk 6 tahun pertama, nanti begitu pekerja semakin banyak dan produksi semakin meningkat, hal itu merupakan objek pajak baru. Akan ada lebih banyak orang yang akan membayar pajak nantinya. Selanjutnya beliau mengungkapkan bahwa sebuah perusahaan yang sudah dalam proses penjualan itu sudah membentuk yang namanya basis pajak. Kalau semua wajib pajak diberikan fasilitas tanpa melihat kapan berproduksi secara komersialnya, maka akan habis semua penerimaan pajak.

Pada`sektor perikanan, adanya insentif ini diharapkan dapat mendukung percepatan pembangunan industri perikanan terutama yang berkaitan dengan program pembangunan Sentra Kelautan dan Perikanan Terpadu (SKPT) di kawasan pulau-pulau terluar yang dekat dekat gateway ekspor. Ke depannya dengan adanya SKPT ini, diharapkan kawasan tersebut dapat menghidupkan ekonomi baru baik bagi nelayan maupun bagi masyarakat sekitar.

\section{c. Extent of Exchange Envinsion}

Menurut Grindle (2980) indikator ini menunjukkan derajat perubahan yang ingin dicapai. Isi dari kebijakan akan mempengaruhi apa yang dihasilkan. Perubahan yang hendak dicapai dapat berupa program jangka panjang yang menuntut adanya perubahan pada perilaku masyarakat.

Fasilitas tax allowance ini pada prinsipnya hanya dapat diberikan pada wajib pajak yang patuh. Karena sebelum dapat mengajukan permohonan fasilitas tax allowance, wajib pajak tersebut harus mempunyai Surat Keterangan Fiskal yaitu surat yang berisi data pemenuhan kewajiban perpajakan Wajib Pajak untuk masa dan tahun pajak tertentu (Kepala Seksi Fasilitas, Badan Kebijakan Fiskal). Hal inilah yang menurut penulis merupakan salah satu faktor yang menyebabkan kurangnya minat investor sektor perikanan untuk berinvestasi. Maraknya kasus transshipment serta pelaporan hasil tangkapan yang tidak sesuai dengan yang semestinya, membuat perusahaan-perusahaan terkesan "takut" untuk berurusan dengan masalah pajak. Mereka tidak mau data Laporan Keuangan mereka diperiksa secara detail sehingga akan ada kemungkinan temuan kewajiban pajak yang lebih besar. Dengan adanya persyaratan Surat Keterangan Fiskal ini berarti mereka harus melaporkan secara benar kewajiban perpajakannya dan harus membayar tunggakan pajak yang belum ataupun kurang dibayarkan.

Hal tersebut sejalan dengan pendapat Kepala Seksi Pelayanan Fasilitas Direktorat Usaha dan Investasi KKP yang menyatakan bahwa terkadang para pengusaha tidak mau menunjukkan berapa investasi yang sebenarnya, karena mereka tidak mau berurusan dengan pajak. Memang nanti mereka tidak mendapatkan keuntungan pajak, tapi akhirnya dia akan melaporkan pajak yang sebenarnya. Masalah Pajak di Indonesia, hanya $30 \%$ orang yang melaporkan hasil yang sebenarnya. Memberikan fasilitas ini sebenarnya juga membuka tabir juga terhadap laporan keuangan perusahaan.

Dengan adanya wajib pajak yang berusaha untuk mau menggunakan insentif ini, maka diharapkan ke depannya pembukuannya menjadi lebih baik, kewajiban perpajakannya dilaksanakan dengan baik. Karena insensit ini memang di granted bagi wajib pajak yang patuh. Hal ini seperti yang dijelaskan juga oleh Kasubbid PNBP Kementeriaan Koordinator Bidang Perekonomian, bahwa konsepnya tiap insentif dan kemudahan itu tidak free. Ada beban administrasi yang harus ditanggung dan kita harus memastikan bahwa insentif ini untuk wajib pajak yang patuh dan baik daam membayar pajak.

Pada prinsipnya, tanpa diberikan fasilitas pun, DJP mempunyai kewenangan untuk menguji Laporan Keuangan suatu perusahaan. Pada pasal 12 KUP, Surat Pemberitahuan Pajak (SPT) itu benar kecuali DJP punya bukti bahwa SPT itu salah. Kalau wajib pajak merasa laporannya sudah benar, maka tidak ada yang perlu dikhawatirka.. Selama 6 tahun sebelum jangka waktu penetapan 
itu berakhir, DJP bisa memeriksa kapan saja. Baik orang yang mendapat fasilitas maupun yang tidak (Kepala Seksi PPh Badan, Direktorat Jenderal Pajak).

\section{d. Site of Decision Making}

Indikator ini menunjukkan bahwa pengambilan keputusan dari suatu kebijakan itu adalah suatu hal yang penting. Dalam pelaksanaan kebijakan tax allowance ini, telah diamanatkan dalam Peraturan Pemerintah Nomor 18 Tahun 2015 bahwa setiap sektor mengatur sendiri kriteria dan persyaratan pada sektornya masingmasing. Pada sektor kelautan dan perikanan, telah terbit Peraturan Menteri Kelautan dan Perikanan Nomor 17 Tahun 2015 sebagai aturan turunan yang mengatur kriteria pemberian tax allowance dan juga sebagai acuan penentuan kelayakan bidang usaha sektor perikanan yang dapat mengusulkan fasilitas tax allowance. Menurut Kepala Seksi Pelayanan Usaha, Direktorat Usaha dan Investasi KKP, kementerian sektor lah yang paling mengetahui bidangnya masing-masing. Berapa nilai investasi perusahaan, apakah sumber bahan bakunya legal, dan sebagainya. Rekomendasi itulah yang nanti menjadi acuan bagi BKPM dan DJP untuk dibuatkan keputusan apakah di terima atau tidak permohonannya.

Hal ini juga dipertegas dengan hasil wawancara dengan Direktorat Deregulasi, Badan Koordinasi dan Penanaman Modal yang menyatakan bahwa tax allowance itu memang diusulkan oleh berbagai pihak, bisa dari pengusaha, bisa dari kementerian teknisnya bisa juga dari BKPM. Namun disetujui atau tidak disetujuinya, terutama dari kementerian sektor lah yang memandang suatu bidang usaha itu perlu atau tidak untuk diberikan fasilitas. Pada sektor perikanan sendiri sejak tahun 2016 sudah terdapat 4 usulan dari pelaku usaha untuk dapat diberikan fasilitas tax allowance. Namun yang mendapatkan fasilitas baru 1 perusahaan. Tiga perusahaan lain ditolak dengan beberapa catatan seperti yang dapat dilihat pada tabel berikut :
Tabel 1. Perusahaan Yang Mengajukan Tax Allowance Pada Sektor Kelautan dan Perikanan

\begin{tabular}{|c|c|c|c|}
\hline $\begin{array}{c}\text { Nama } \\
\text { Perusahaan }\end{array}$ & $\begin{array}{l}\text { Bidang } \\
\text { Usaha }\end{array}$ & $\begin{array}{l}\text { Rencana } \\
\text { Investasi }\end{array}$ & Keterangan \\
\hline $\begin{array}{l}\text { PT. Bumi } \\
\text { Pangan } \\
\text { Utama }\end{array}$ & $\begin{array}{l}\text { Industri } \\
\text { Pembekuan } \\
\text { Biota } \\
\text { lainnya }\end{array}$ & $\begin{array}{l}\text { Rp. } 300 \text { Milyar di } \\
\text { Banten (PMDN) }\end{array}$ & $\begin{array}{l}\text { Tidak mendapat } \\
\text { TA karena } \\
\text { pengajuan setelah } \\
\text { perusahaan } \\
\text { beroperasi secara } \\
\text { komersial }\end{array}$ \\
\hline PT. Perinus & $\begin{array}{l}\text { Industri } \\
\text { Pembekuan } \\
\text { Ikan }\end{array}$ & $\begin{array}{l}\text { Rp. 1,34 Milyar } \\
\text { di Maluku, Malut, } \\
\text { Papua Barat, } \\
\text { Sulut, Sulsel, } \\
\text { Pekalongan, } \\
\text { Sidoarjo (PMDN) }\end{array}$ & $\begin{array}{l}\text { Tidak dapat } \\
\text { memisahkan } \\
\text { aktiva perluasan } \\
\text { usaha }\end{array}$ \\
\hline $\begin{array}{l}\text { PT. Wahan } \\
\text { Lestari } \\
\text { Investama }\end{array}$ & $\begin{array}{l}\text { Budidaya } \\
\text { Udang } \\
\text { Terintegrasi }\end{array}$ & $\begin{array}{l}\text { Rp. } 786 \text { Milyar } \\
\text { (Korea - PMA) }\end{array}$ & $\begin{array}{l}\text { Izin prinsip terbit } \\
\text { sebelum terbitnya } \\
\text { PP } 18 / 2015\end{array}$ \\
\hline $\begin{array}{l}\text { PT. Indomia } \\
\text { Langgeng } \\
\text { Sejahtera }\end{array}$ & $\begin{array}{l}\text { Pembekuan } \\
\text { Biota Air } \\
\text { Lainnya }\end{array}$ & $\begin{array}{l}\text { Rp. } 222 \text { Milyar } \\
\text { (Lampung } \\
\text { PMDN) }\end{array}$ & $\begin{array}{l}\text { SK MenKeu No. } \\
\text { 97/K.3/2017 } \\
\text { tentang } \\
\text { Persetujuan } \\
\text { Pemberian } \\
\text { Fasilitas Pajak } \\
\text { Penghasilan } \\
\text { Penanaman Modal } \\
\text { (TA) }\end{array}$ \\
\hline
\end{tabular}

Sumber : Direktorat Usaha dan Investasi, Kementerian Kelautan dan Perikanan

Dari hasil penelitian, salah satu faktor yang menurut penulis menyebabkan rendahnya realisasi pemanfaatan tax allowance adalah kesalahan pemahaman dari kementerian sektor terhadap kriteria dan persyaratan yang ada pada Peraturan Pemerintah Nomor 18 Tahun 2015 dan Permen KP Nomor 17 Tahun 2015. Adapun kriteria dan syarat pemberian fasilitas ini adalah mempunyai nilai investasi yang tinggi atau untuk ekspor; atau memiliki penyerapan tenaga kerja yang besar; atau memiliki kandungan lokal yang tinggi. Hal ini berarti jika salah satu kriteria atau syarat terpenuhi, maka pelaku usaha tersebut sudah dapat mengajukan usulan dan dipertimbangkan dalam pemberian fasilitas tax allowance.

Namun dalam pelaksanaannya, pelaksana dari kementerian sektor menerjemahkan kriteria dan syarat tersebut sebagai syarat kumulatif, dimana semua syarat harus dipenuhi sesuai dengan yang tertera di Lampiran II Permen KP Nomor 17 Tahun 2015 seperti memiliki nilai investasi tinggi (paling sedikit $10-50$ milyar) atau untuk ekspor (paling sedikit 30\% - 80\% hasil 
produk diekspor) atau memiliki penyerapan tenaga kerja yang besar (paling sedikit 90\% tenaga kerja Indonesia). Hal ini sejalan dengan hasil wawancara dengan Kepala Seksi Pelayanan Usaha, Direktorat Usaha dan Investasi, KKP yang menyatakan bahwa tidak mudah untuk memberikan fasilitas. Kriteria/syarat yang ada itu adalah kumulatif, yang artinya bila ada salah satu yang tidak terpenuhi maka tidak bisa menerima fasilitas pajak. Beliau menambahkan bahwa setiap KBLI ada daerahnya. Walaupun secara kriteria sudah lolos, KBLI lolos, lokasi lolos, tenaga kerja lolos, orientasinya ekspor, kemudian dilihat lagi apakah perusahaan itu ekspor atau tidak dan berapa penyerapan tenaga kerjanya.

Setelah penentuan kelayakan oleh kementerian pembina sektor, selanjutnya pengambilan keputusan dilakukan melalui rapat trilateral yang melibatkan para pejabat Eselon I dari masingmasing sektor, BKPM, serta Staf Ahli Bidang Kebijakan Penerimaan Negara Kementerian Keuangan. Dalam rapat ini diuji lagi kelayakan pelaku usaha tersebut, termasuk dari sisi pajak. Apakah mereka wajib pajak yang patuh atau tidak. Jika hasil rapat trilateral menyatakan pelaku usaha tersebut berhak menerima tax allowance, maka akan diterbitkan Surat Keputusan Menteri Keuangan mengenai pemberian fasilitas pajak penghasilan berupa tax allowance kepada pelaku usaha tersebut.

\section{e. Program Implementer}

Merupakan indikator yang menunjukkan bahwa dalam melaksanakan suatu kebijakan perlu didukung oleh ketersediaan pelaksana yang kompeten demi terwujudnya keberhasilan suatu kebijakan. Pemberian fasilitas tax allowance menimbulkan tax expenditure oleh pemerintah, sehingga tax allowance tidak akan dengan mudah diberikan tanpa melibatkan para implementer yang kompeten. Menurut Kepala Seksi Fasilitas, Badan Kebijakan Fiskal, implementasi kebijakan tax allowance ini terdiri dari menjadi 2 bagian. Pertama terkait dengan regulasi, yaitu batang tubuh kebijakan tersebut. Dalam hal ini Badan Kebijakan Fiskal berperan dalam penentuan
Subjek, Objek, dan Tarif (SOT), Direktorat Jenderal Pajak berperan dalam regulasi yang bersifat administratif, dan Badan Koordinasi Penanaman Modal berkaitan dengan segala hal yang berkaitan dengan penanaman modal. Kedua, yaitu yang terkait dengan berbagai sektor. Dalam hal ini yaitu yang terkait dengan Kementerian Pembina sektor, akan dikoordinasikan oleh Kementerian Koordinator Bidang Perekonomian. Ada beberapa sektor yang terdapat pada Lampiran I dan II PP 18 Tahun 2015 jo. PP 9 Tahun 2016, dan Kemenkoper yang dirasa tepat untuk mengkoordinasikan berbagai Kementerian/ Lembaga tersebut terkait dengan pelaksanaan kebijakan tax allowance ini.

Disamping peran pembina sektor sebagai ujung tombak pertimbangan pemberian tax allowance, terdapat juga peran Direktorat Jenderal Pajak pasca dikeluarkannya SK Menteri Keuangan mengenai pemberian tax allowance kepada pelaku usaha. Berdasarkan hasil wawancara dengan Kepala Seksi PPh Badan, DJP, bahwa posisi Direktorat Jenderal Pajak sendiri adalah pada post-audit. Wajib pajak yang mendapatkan fasilitas akan menjadi objek yang diawasi karena ada beberapa larangan yang tidak boleh dia lakukan, sepanjang perusahaan memanfaatkan fasilitasnya (5\% selama 6 tahun). Tugas rutin dari DJP adalah pengawasan terhadap pelaporan, apakah ada keganjilan atau apakah ada laporan yang bermasalah. Selama 5 tahun sebelum jangka waktu penetapan itu berakhir, DJP bisa melakukan pemeriksaan kapan saja. Baik terhadap wajib pajak yang mendapat fasilitas maupun yang tidak mendapat fasilitas.

\section{f. Resources committed}

Merupakan indikator yang menunjukkan bahwa pentingnya ketersediaan sumber daya yang mendukung terlaksananya kebijakan yang telah dibuat. Berdasarkan hasil wawancara dengan para informan, terlihat bahwa para implementor berkomitmen untuk terus memaksimalkan pelaksanaan kebijakan ini. Salah satunya terlihat dari proses evaluasi yang secara berkala dilakukan untuk merevisi bidang-bidang 
usaha yang bisa ditambahkan atau bahkan dihapuskan. Informan dari Direktorat Deregulasi Badan Koordinasi Penanaman Modal menyatakan bahwa evaluasi dilakukan setidaknya setiap 2 tahun. Jika ada bidang usaha yang sudah ada dari peraturan-peraturan sebelumnya tapi tidak dimanfaatkan, ada kemungkinan untuk ditutup. Namun jika ada usulan untuk mempertahankan bidang usaha yang sudah ada atau menambahkan bidang usaha baru, juga tetap dipertimbangkan untuk mendorong sektor tersebut.

Saat ini sedang dilakukan revisi PP No. 18 Tahun 2015 jo PP No. 9 Tahun 2016 dalam rangka penyederhanaan prosedur dan percepatan berusaha sesuai amanat pada Perpres No. 91 Tahun 2017. Proses pengajuan permohonan fasilitas tax allowance pun nantinya akan menggunakan Online Single Submission (OSS) dimana proses penerbitan SK yang semulanya 25 hari akan dipangkas menjadi 5 hari kerja. Penerapan OSS ini nantinya juga akan memudahkan para investor baru maupun yang akan memperluas usahanya untuk memperoleh informasi mengenai fasilitas tax allowance (Kepala Seksi Fasilitas Badan Kebijakan Fiskal)

Direktorat Jenderal Pajak juga menyatakan komitmennya untuk menjalankan kebijakan ini sesuai aturan yang ada. Kepala Seksi PPh Badan DJP menyatakan "saat ini kita bicara bukan hanya tentang pajak, tetapi tentang Indonesia. Memang ada belanja pajak oleh pemerintah, namun dalam suatu lingkup bisnis itu juga terdapat supplier, human resources, dan sebagainya. Secara umum jika tidak ada investasi yang masuk, maka juga tidak ada potensi pajak yang masuk. Dengan adanya investasi baru, maka ekonomi disekelilingnya juga akan bergerak dan timbul potensi pajak baru. Direktorat Jenderal Pajak sangat concern dengan hal ini. Cara melihatnya bukan lagi pada satu titik, tapi pada satu ring di dalam lingkup itu".

\section{Context of Implementation}

\section{a. The power, interests and strategies of the actors involved}

Sektor yang terdapat dalam lampiran PP 18/2015 jo. PP 9/2016 adalah sektor-sektor yang mendapatkan prioritas tinggi dalam pembangunan nasional. Dalam pelaksanaan tax allowance di berbagai kementerian sektor tentunya terdapat perbedaan. Hal ini dikarenakan tugas pokok dan fungsi setiap kementerian sektor itu berbeda-beda. Adapun jumlah bidang usaha pada lampiran kebijakan tax allowance dan pemanfaatannya dapat dilihat pada tabel berikut:

Tabel 2. Jumlah Bidang Usaha dan Pemanfaatannya hingga Tahun 2018

\begin{tabular}{|l|c|c|c|}
\hline \multirow{2}{*}{ Sektor } & \multicolumn{3}{|c|}{ Jumlah KBLI } \\
\cline { 2 - 4 } & $\begin{array}{c}\text { Lampiran } \\
\text { I }\end{array}$ & $\begin{array}{c}\text { Lampiran } \\
\text { II }\end{array}$ & $\begin{array}{c}\text { Pemanfaat } \\
\text { an }\end{array}$ \\
\hline Industri & 68 & 27 & 32 \\
\hline $\begin{array}{l}\text { Energi dan Sumber Daya } \\
\text { Mineral }\end{array}$ & 6 & 11 & 8 \\
\hline Kelautan dan Perikanan & - & 11 & 1 \\
\hline Transportasi & 2 & - & \\
\hline Pertanian & 2 & 7 & \\
\hline Environment and Forestry & 1 & 9 & \\
\hline Public Works and Housing & 1 & - & \\
& & & \\
\hline Tourism & 1 & - & \\
\hline Total & 81 & 65 & 41 \\
\hline
\end{tabular}

Sumber: Direktorat Fasilitas, Badan Koordinasi dan Penanaman Modal

Pemanfaatan fasilitas tax allowance paling tinggi adalah pada sektor Industri dengan total 32 penerima fasilitas, sektor Energi dan Sumber Daya Mineral dengan 8 penerima fasilitas dan pada urutan ke-3 adalah sektor Kelautan dan Perikanan dengan 1 penerima. Meskipun realisasi sangat rendah, namun menurut Kepala Seksi Pelayanan Usaha, Direktorat Usaha dan Investasi KKP, 1 penerima fasilitas tax allowance yang tercatat itu merupakan suatu keberhasilan, karena sektor perikanan sendiri punya persyaratan yang tidak mudah. Dan jika dibandingkan dengan sektor lain, realisasi sektor kelautan dan perikanan sudah lebih baik dibandingkan dengan beberapa sektor lain yang realisasinya masih nihil. 
Menurut hasil wawacara dengan Kasubbid PNBP, Kementerian Koordinator Bidang Perekonomian, sektor perindusrian memang lebih cocok dengan karakter dari tax allowance ini sendiri. Sektor industri punya banyak aset tetap yang jelas manfaatnya lebih dapat diukur. Sedangkan di kelautan dan perikanan terdapat kendala seperti tidak banyaknya aset tetap berupa tanah dan bangunan, melainkan aset berupa kapal dan alat-alat penangkapan ikan dan didominasi oleh nelayan-nelayan kecil. Investor mungkin melihat bahwa insentif tersebut kurang memberikan manfaat, atau secara ekonomis tidak efisien dibandingkan beban administrasi yang harus ditanggung dalam proses mendapatkan fasilitas tersebut.

Selain itu, diantara para stakeholder juga memiliki kepentingan yang berbeda-beda karena tugas pokok dan fungsinya berbeda. Misalnya kementerian teknis seperti perindustrian, ESDM, dan KKP, tentu berperan untuk memajukan atau menggerakan sektor yang dibidanginya. Sebisa mungkin mereka akan mengusulkan sebanyak mungkin bidang usaha. Sementara di Kementerian Keuangan sendiri, ada amanat untuk menjaga penerimaan Negara. Jadi harus memastikan bahwa Negara sudah memberikan fasilitas pengurangan pajak secara tepat. Jangan sampai fasilitas diberikan dengan mudah tanpa melalui proses yang benar sehingga berdampak pada APBN di masa yang akan datang.

\section{b. Characteristics of the institutions and regimes in power}

Dalam rangka menjaga kedaulatan kelautan dan perikanan Indonesia, terdapat kebijakankebijakan strategis yang dikeluarkan. Salah satunya adalah kebijakan mengenai moratorim kapal asing seperti yang diamanatkan dalam Peraturan Preseiden Nomor 44 Tahun 2016 tentang Daftar Bidang Usaha yang Tertutup dan Bidang Usaha yang Terbuka dengan Persyaratan di Bidang Penanaman Modal. Adanya peraturan ini menyebabkan usaha perikanan tangkap tertutup untuk asing dan hanya boleh dikelola oleh investor dalam negeri.
Pelaksanaan tax allowance tentu harus sejalan dengan peraturan di atasnya. PP No. 18 Tahun 2015 jo. PP No. 9 Tahun 2016 tentang Kriteria dan/atau Persyaratan Pemberian Fasilitas Penanaman Modal pada Bidang-bidang Usaha Tertentu dan/atau Daerah-daerah Tertentu, tidak bisa dipisahkan dari PP No. 44 Tahun 2016, sehingga hal tersebut secara tidak langsung memberikan pengaruh terhadap realisasi pemanfaatan fasilitas pajak penanaman modal di sektor perikanan. Menurut Kepala Seksi Fasilitas, Direktorat Usaha dan Investasi KKP, sektor perikanan memerlukan investasi yang besar seperti kapal, alat penangkap ikan, dan infrastruktur dalam usaha pengolahan ikan. Selama ini yang mengelola usaha penangkapan ikan adalah asing. Tidak banyak investor dalam negeri yang sepenuhnya sanggup untuk berinvestasi pada sektor perikanan ini.

Dari hasil penelitian dari beberapa informan, peningkatan investasi tidak hanya semata-mata ditentukan oleh insentif pajak. Fasilitas pajak dapat dikatakan sebagai "sweetener" dimana banyak faktor-faktor lain yang sangat mempengaruhi investasi seperti stabilitas politik, stabilitas ekonomi, keamanan dan ketersediaan infrastruktur. Jika investor merasa semua faktor dasar tersebut telah terpenuhi, maka mereka akan berinvestasi. Indonesia sendiri saat ini termasuk ke dalam Negara dengan situasi politik dan ekonomi yang stabil. Indonesia juga merupakan pasar yang luar bisa bagi bisnis global. Ditambah lagi dengan ritme pimpinan Kementerian Kelautan dan Perikanan sekarang, sektor kelautan dan perikanan mempunyai banyak ruang untuk menggali investasi yang lebih besar. Selanjutnya menurut Kepala Seksi PPh Badan, Direktorat Jenderal Pajak, jika pelaku bisnis mengetahui bahwa ada fasilitas, sangat tidak mungkin jika mereka tidak tertarik. Karena dengan fasilitas pengurangan pajak tersebut, mereka akan mendapatkan tax-savings dengan jumlah yang besar. 


\section{c. Compliance and responsiveness}

Salah satu penyebab kecilnya realisasi pemanfaatan tax allowance di sektor perikanan adalah karena kurangnya kepatuhan dari kementerian pembina sektor. Berdasarkan hasil wawancara dengan Badan Koordinasi dan Penanaman Modal serta Badan Kebijakan Fiskal, Kementerian Kelautan dan Perikanan tidak terlalu aktif dalam berkoordinasi dengan para pelaksana kebijakan. Dikatakan bahwa KKP jarang menghadiri rapat koordinasi yang diselenggarakan oleh para penanggungjawab dan pelaksana kebijakan tax allowance. Kepala Seksi Fasilitas Badan Kebijakan Fiskal mengatakan, kalaupun datang menghadiri, tidak pernah mengutus orang yang sama. Sehingga informasi tidak diterima secara utuh. Karena dalam pelaksanaan kebijakan ini diperlukan orang yang kompeten dan menerima informasi secara berkesinambungan.

Faktor lain adalah kurangnya sosialisasi kepada pelaku usaha, sehingga banyak wajib pajak yang tidak tau mengenai tax allowance. Menurut Kepala Seksi Fasilitas BKF, sosialisasi dilakukan bukan hanya saat kebijakan itu terbit, tetapi secara continue. Karena akan banyak industry-industri baru yang muncul. Karena saat ini masih banyak yang belum mengetahui bahwa adanya fasilitas pajak penanaman modal. Dan sudah terlambat dan sulit mengajukan jika sudah berproduksi secara komersial.

Menurut Kepala Seksi Pelayanan Usaha, Direktorat Usaha dan Investasi KKP, sosialisasi sudah dilakuakan dua kali dalam setahun dengan mengundang perusahaan-perusahaan yang potensial dalam perpajakan. Dalam sekali sosialisasi dapat dihadiri oleh $40-100$ perusahaan. Namun yang mengusulkan memang sedikit. Adapun kendala di internal KKP sendiri adalah kurangnya koordinasi antar beberapa direktorat yang seharusnya berperan dalam implementasi kebijakan tax allowance ini. Jika melihat dari jenis bidang usaha yang terdapat pada lampiran peraturan tax allowance, maka setidaknya ada 3 direktorat yang terlibat dalam pelaksanaan kebijakan ini yaitu Direktorat
Jenderal Perikanan Tangkap (DJPT), Direktorat Jenderal Perikanan Budidaya (DJPB), dan Direktorat Jenderal Penguatan Daya Saing Produk Kelautan dan Perikanan (PDSPKP). Namun yang selama ini melakukan sosialisasi hanya Ditjen PDSPKP yatiu yang berkaitan dengan industri pengolahan ikan. Hal ini ditegaskan dalam wawancara dengan Kepala Seksi Pelayanan Usaha, Direktorat Usaha dan Investasi, Ditjen PDSPKP yang mengatakan bahwa mereka tidak kenal dengan pengusaha yang di hulu karena bukan ranahnya industri pengolahan ikan. Seharusnya harus besar sosialisasinya dan bisa menjangkau semua bidang usaha tapi tidak ada koordinasi.

Selain masalah sosialisasi, Kepala Seksi PPh Badan DJP mengatakan bahwa KKP belum tepat dalam mendeteksi bidang usaha apa saja yang seharusnya diberikan fasilitas. Jika KKP sudah mempunyai rencana pengembangan investasi, seharusnya sudah mengetahui arah pembangunan sektor perikanan. Berarti ada potensi investasi baru diluar investasi yang sudah ada. Itulah yang menjadi target untuk diberikan fasilitas. Pendapat yang sejalan juga disampaikan oleh Kepala Seksi Fasilitas BKF, bahwa ada kemungkinan dalam penyusunan kriteria dan/atau persyaratan pemberian tax allowance di sektor perikanan, tidak sesuai dengan kenyataan di lapangan sehingga kurang applicable.

Seperti yang telah dibahas pada indikator sebelumnya, bahwa proses permohonan pengajuan tax allowance akan dilakukan melalui sistem OSS yang hanya membutuhkan waktu 5 hari kerja. Hal ini adalah bentuk respon dari pelaksana kebijakan dalam rangka memperbaiki pelaksanaan kebijakan tax allowance yang selama ini belum maksimal. Menurut Kepala Subbid PNBP, Kemenkoper, bahwa sistem OSS membawa message utama dalam memberikan kepastian, kemudian memberikan kemudahan karena tidak perlu bertemu muka. Koordinasi juga tidak perlu dilakuakan melalui rapat trilateral melainkan semua dilakukan by sistem. Walaupun masih sederhana, tapi sudah meng-eliminate pertemuan yang harus dihadiri oleh eselon I. 


\section{SIMPULAN DAN SARAN}

Tidak maksimalnya pelaksanaan kebijakan tax allowance disektor perikanan utamanya disebabkan oleh kurangnya koordinasi internal oleh Kementerian Kelautan dan Perikanan selaku pembina sektor. Hal ini menyebabkan sosialisasi menjadi kurang maksimal karena belum mengerahkan semua sumber daya yang ada terkait pelaksanaan kebijakan tax allowance. Konten dari kebijakan yang memuat kriteria dan/atau persyaratan pemberian tax allowance, dikhawatirkan menjadi penghambat implementasi karena kurang applicable bagi pelaku usaha disektor perikanan.

Dalam rangka memaksimalkan pemanfaatan tax allowance di sektor kelautan dan perikanan, Kementerian Kelautan dan Perikanan sebagai pembina sektor harus meriviu kembali bidangbidang usaha tertentu dan daerah-daerah tertentu yang applicable terhadap fasilitas tax allowance. KKP juga harus dapat merumuskan kriteria dan/atau persyaratan dalam pengajuan fasilitas pajak, yang sesuai dengan kenyataan di lapangan, karena kriteria yang ada sekarang tampak terlalu menyulitkan para pelaku usaha. Peran KKP dalam sosialisasi kepada para pelaku usaha harus lebih dilakukan secara aktif, karena dikhawatirkan para pelaku usaha tidak mendapatkan informasi yang cukup mengenai adanya fasilitas pengurangan pajak penghasilan dalam penanaman modal di sektor kelautan dan perikanan.

\section{DAFTAR PUSTAKA}

Badan Koordinasi dan Penanaman Modal. 2017. Domestic and Foreign Direct Investment Realization in Quarter II and January June 2017

Creswell, John. 1994. Qualitative and Quantitative Approach. California : Sage Publication
Easson, Alex. 2004. Tax Incentives for Foreign Direct Investment. Netherlands : Kluwer Law International

Grindle, Merilee S. 1980. Politics and Policy Implementation in the Third World. New Jersey : Princeton University Press

James P. Lester \& Joseph Stewart. 2000. Public Policy: An Evolutionary Approach. California : Wadsworth Thomson Learning

Kementerian Kelautan dan Perikanan. 2018. Laut Kita Masa Depan Bangsa : Akses Modal Mendorong Kesejahteraan

Kementerian Kelautan dan Perikanan. 2018. Laut Kita Masa Depan Bangsa : Upaya tingkatkan produksi dan ekspor produk perikanan Indonesia

Kementerian Kelautan dan Perikanan. 2019. Laporan Kinerja Kementerian Kelautan dan Perikanan Tahun 2018

Kristian Widya Wicaksono. 2018. Tipologi Inovasi Sektor Publik Pada Tiga Program Inovatif Pemerintah Daerah Kota Surabaya (Tinjauan Reflektif terhadap Tiga Inovasi Pelayanan Publik Pemerintah Kota Surabaya Tahun 2018). Vol. 1 No. 2. Jurnal Manajemen Pelayanan Publik. Universitas Padjadjaran.

Maradona, Ian. 2013. Implikasi Ketentuan Insentif Pajak (Tax Holiday/ Tax Allowance) terhadap Penanaman Modal di Indonesia. Jakarta : Program Magister Hukum Universitas Indonesia

Nunung Runiawati. 2017. Pemanfaatan Barang Milik Daerah (Suatu Pendekatan Teoritis dan Praktis Dalam Menentukan Metode Pemanfaatan Aset). Vol. 1 No. 1. Jurnal Manajemen Pelayanan Publik. Universitas Padjadjaran. 
Peraturan Pemerintah Nomor 9 Tahun 2016 tentang Perubahan atas Peraturan Pemerintah Nomor 18 Tahun 2015 tentang Fasilitas Pajak Penghasilan untuk Penanaman Modal di Bidang-bidang Usaha Tertentu dan/atau di Daerah-daerah Tertentu

Peraturan Menteri Kelautan dan Perikanan Nomor 17 Tahun 2015 tentang Kriteria dan/atau Persyaratan Pemberian Fasilitas Pajak Penghasilan Untuk Penanaman Modal di Bidang-bidang Usaha Tertentu dan/atau di Daerah-daerah Tertentu Pada Sektor Kelautan dan Perikanan

Ridgway and Thalib. 2003. Globalization and Development: Free Trade, Foreign Aid, Investment and The Rule of Law. California Western International Law Journal, Vol 33

Rosdiana, Haula and Edi Slamet Irianto. 2012. Pengantar Ilmu Pajak : Kebijakan dan Implementasi di Indonesia. Jakarta : Rajawali Pers

Santoso, Iman dan Ning Rahayu. 2013. Corporate Tax Management : Mengulas Upaya Pengelolaan Pajak Perusahaan Secara Konseptual-Praktikal. Jakarta : Observation \& Research of Taxation (ortax)

Turonyi, Victor. 1998. Tax Law Design and Drafting : Volume 2. Washington DC : IMF

Wulandari, Pretty dan Putranti, Titi Muswati. 2013. Evaluasi Kebijakan Pemberian Insentif Pajak Penghasilan pada Industri Pengolahan Kelapa Sawit di Indonesia. Jakarta : Fakultas Ilmu Sosial dan Ilmu Politik Universitas Indonesia. 